\title{
Tragedy in the Theatre: Interview with Director Phillip Mann
}

\section{David Groves}

A stage performance is a theatrical text combining many different aspects or codes, of which the dramatic text is only one. Aristotle began his treatment of the art of poetry by focusing on tragedy and eventually singling out six elements, those of Plot, Character, Language, Thought, Spectacle, and Melody; he then singled out Plot as the prime element, while commenting that Spectacle "is attractive, but is very inartistic and is least germane to the art of poetry."

Each dramatic text has the potential for an infinite number of stage readings according to the linguistic, cultural and theatrical conventions of the time and place into which it is translated. Surely, whatever other feelings Sophocles or Shakespeare might have had on seeing an eighteenth or twenty-first century modern English or Japanese production of Oedipus Rex or Macbeth, the overriding one would have been of bemused-perhaps amused if they weren't to die of shock first-astonishment.

Since the drama is realised in performance, the present volume on tragedy seems to require at least some intervention by a practitioner. One of the most important figures in New Zealand theatre over recent decades-particularly in the Wellington area although his practice has extended beyond Wellington and beyond New Zealand-has been Phillip Mann. I chose to interview him because of his extensive experience and distinctive style and philosophy. It should be superfluous to emphasise that in the impure world of theatrical practice there is no "correct" answer to any of the generalising questions put. One would expect Phillip Mann (whom I explicitly invited to speak as both academic and director, bringing all his experience to bear in discussing the topic), to handle the term "tragedy" with confidence. He has, after all, lectured on Artistotle.

The edited interview sketches out a wide area of practice; and if there is any conclusion to be drawn, it is perhaps that in the rehearsal room the word "tragedy" is not helpful as a description, 
but that it is a possibly useful heuristic tool if used with discrimination and caution.

Phillip Mann arrived in New Zealand in 1969 to create the Department of Drama at Victoria University. His brief was not to set up a department of theatre history but to explore, by practical workshops and productions, the theatrical dimensions of dramatic texts. He immediately also became deeply involved in the professional theatre rapidly developing in New Zealand at that time, particularly at Wellington's Downstage Theatre. Thus Phillip Mann was at the time of the interview (he retired from Victoria University in 1998) at once a senior academic and one of the finest directors in Wellington, unparalleled for marshalling large-scale forces in productions of epic sweep, with the Greek tragedians, Shakespeare and Brecht among his favoured authors. His professional productions of his beloved Greeks have spanned his Bacchae at Downstage in 1970, to the Downstage Agamemnon in 1997, while of his Shakespeares, the following interview makes particular reference to his Downstage Othello in 1989.

It is worth recalling that the genre of opera was originally invented in Italy as an attempt to revive what people at that time thought might have been Greek tragedy (with its spectacle and melody), and Phillip Mann has also directed operas of the standard repertoire in New Zealand: in the genre of "tragedy" may be numbered his Madama Butterfly (1999) for Canterbury Opera.

The original interview with Phillip Mann took place in his office at Victoria University on 16 June 1998 over a bottle of red wine [and was updated by Phillip Mann in 2010 (Eds)]. I have divided the presentation into four sections: 1) Mann's reactions to general questions of genre; 2) Mann on the pros and cons of Aristotle, with some reference to Brecht; 3) Mann's comments on on particular productions; 4) music and opera. In deciding whether to go from the general to the particular, or vice-versa, I thought it appropriate for this book to follow Aristotle and begin with the million-dollar question. 


\section{Literary genre in theatrical space}

David Groves What is the use, if any, for the practitioner in the theatre of the generic terms "tragedy," "comedy," "farce," "tragicomedy"? Are they a help or a hindrance?

Phillip Mann As a teacher I used to enjoy exploring and explaining terms such as these. But as a practitioner, I think that those terms could be a hindrance. They are analytic tools, valuable as a way of understanding what has happened in a play, but problematic as a guide on how to proceed when directing. As you say, they are genre terms, and directors deal with individual plays which may or may not exemplify the genre. When you are directing a Greek play, you come very close to the inevitability enshrined in its structure. This is a step beyond theory. The living reality of anagnorisis - that is the moment of recognition when the tragic hero realises the way in which his every action has led to his downfall-is something which has to be built towards, and when it occurs, it is akin to a landslide or a tsunami. The strange thing is, when you experience such things in the rehearsal room, you can reach a point of freedom, and at such times you control the genre. Certainly I felt something like that when I directed the Bacchae. After struggling to understand the play, I suddenly felt a tremendous freedom within the tragedy. Your job as a director is to give the audience as close an experience as you can-but you can't do that from the outside. It would be like talking about meditation without ever sitting down to meditate. So I would say to anyone, "Read the Poetics by all means. But then put the book away when you come to direct."

Of course, this whole question is complicated by translations [of tragedies]. Some translations can be very faithful to the words of the Greek, but miss the tragedy. Others, with greater freedom, might go away from the original play in the hope of capturing its essence. As a director you have to 
make up your own mind and, as in all art, you have to find your own way.

However, one thing is certain, genre terms would certainly create problems if they were followed in a prescriptive sense-i.e., like rules. Consider Corneille...

At the same time, I have to admit that if you know what you are looking for, a label like "tragedy" or "comedy" or "farce" can be quite a help as it directs your attention and focuses your mind in a certain direction. So if I read The Tragical History of Doctor Faustus, that word Tragical gives the play already a certain kind of vividness in my imagination. I should be looking for those elements which I would regard as being the hallmarks of tragedy - a sense of waste, of hopes misled, of reversal of fortune and wisdom gained through pain, perhaps also of inevitability. In a production I would be seeking to reveal those elements.

I suppose the corollary to what I'm saying is that if you're going to direct a play within a distinct genre, it is important that you have a knowledge of the literature which informs that genre. Without that you're really going to be in trouble. For instance, you will find yourself totally at sea with someone like Chekhov if your knowledge of comedy comes from Aristophanes. Although Chekhov calls his plays "comedies," they're not comedies in the normal sense of the word, but they have finally a sort of transcendental vision which might be classed as "la comédie humaine." When you see the totality of life laid out before you - the ignorance, the irony, the frustrated hopes, the vanity - it does have a certain comic grandeur.

But to return to tragedy for a moment, the tragic vision is, I believe, one which locates human beings and their actions against the background of a fate which they cannot control. Dignity persists in being able to stand up to fate and face that fact. If you look at the worst case, everything else must be better-that is hope. The background to tragedy is 
frequently one of relative absurdity, but what is not absurd is human dignity, the ability of human beings to live and strive despite disaster. And then there is the sense of waste that accompanies tragedy, because tragic figures are always in some sense good figures who act in accordance with their beliefs, and are brought to disaster. But it is the dignity and courage that counts in the end-and that explains why tragedies are sobering, but not sad.

David Groves Could you talk about one play which for you illustrates as fully as any other what you understand by the term "tragedy"? Aristotle goes for Oedipus The King. So what's your equivalent?

Phillip Mann Me and Aristotle, eh? Well, as I say, within the genre of tragedy there are many different complexions. However, a play which I regard as being a touchstone for understanding European tragedy is King Lear. Lear says at one point that if you can still say "I hope", then you have not yet reached the bottom. That play gets very close to the point of displaying the worst things you could ever conceive, total chaos, total meaninglessness, randomness and pain. And the end of the play cannot heal the scars caused by the suffering. Death cures nothing. As Kent says,

Vex not his ghost; $\mathrm{O}$, let him pass. He hates him That would upon the rack of this tough world Stretch him out longer.

But that is Shakespeare, and it is a play I rather fear. I am sure if ever I were to direct it, it would knock the stuffing out of me. I'll try to come back to this later.

The Greeks do things a bit differently. Let's just take the Bacchae for a moment, which is a difficult tragedy to come to terms with but a play which has taught me a great deal, and which I have come to relish-yes, one can relish tragedy. The length of time from the moment when the 
tragedy reaches its absolute peak, its crisis, which I take to be the moment when Agave comes storming onto the stage, her mind dazed by Dionysus and holding up a severed head which she believes is the head of a lion... well, then we get her slow realisation, her anagnorisis, as she comes to know it is the head of her son she carries, and that it is he whom she has killed. Now, the length of time from that pivotal moment-surely one of the greatest in world dramathrough to the end of the play is quite long. There's a slow taking down, a time for explanation and sorrow, and this allows the audience to breathe deeply, get their bearings and contemplate the significance of what they have seen. It is a quiet, sorrowful and dignified period. And it often ends with music.

The play does not end with the suddenness of a punch, as occurs quite often in Shakespeare. I am thinking of the ending of Macbeth or Romeo and Juliet when the play ends with a needless death, and you're left aghast — a moment that was captured beautifully I thought in the film Shakespeare in Love. This is what I mean when I say the scars are not healed. This is not a failure in Shakespeare's drama. It's a different kind of satisfaction, a different kind of tragedy. You have to dig for the meaning. It's not presented to you.

So there you are, you asked for one play and you got two. And I've just realised that the older I get, the more I admire Aristotle.

David Groves Maybe I could insert something here. There's a sentence in Peter Brook's The Empty Space, where, referring to a particular production, he says that the costumes and manner of speaking were those of everyday, but that the positioning on stage had the "formality of tragedy." What do you think of the idea that tragedy has a certain formality?

Phillip Mann I don't remember that quote so I'm only guessing, but possibly what he's getting at is that because tragedy is finally very serious and deals with fate and the consequences 
of rash action by people of some power-even if you're looking at a play such as Woyzeck -it needs time for the effect of tragedy to be achieved. Now that implies a certain formality, a working through. It's not casual or random and the stages leading to the final catastrophe are quite logical and the consequence of error. But certainly tragedies are formal - that is one of the things that hold them together: only strong art can face chaos.

Comedy may also begin with error, and it shows us people coping with things going wrong. Mistake builds on mistake, and it's all happening really quite rapidly, but with a sense that it will all come right in the end. And there is the difference. But slow it down, slow comedy down, and it begins to transform. Not necessarily to tragedy, but perhaps to the tragicomic. Fate becomes more evident. The human cost becomes more real. It would be interesting to see what would happen if we took a comedy such as The Importance of being Earnest and treated it as a tragedy. If Lady Bracknell thought for a long time before she said "a handbag?", and then uttered the line as though it really mattered to her-then you would be imposing a certain kind of formality upon that text and it would certainly negate the humour. I am not sure what one would achieve... It hardly bears thinking about, does it? (laughs)

One play which does share the dimensions of tragedy and comedy is Moliere's Tartuffe. It can be played to be very funny, but it can also, as Depardieu showed, be performed with a frightening, menacing quality in which Tartuffe is more like Iago. In the end it is only divine intervention, in the form of the king, that averts the catastrophe. Perhaps we can say that as the drama becomes more formal, so it moves away from randomness and thus deeper issues become more evident. Just a thought.

I'm sorry I've gone away from your quote. I think I'd need to know more of the circumstances to understand it. 
$* * *$

\section{Mann on Aristotle}

David Groves What do you make of Aristotle's phrase that tragedy effects through pity and fear the catharsis of such emotions? Looking at tragedy from the point of view of the audience, thinking of the psychology of the audience, what does tragedy do to you?

Phillip Mann I've got two thoughts on that specifically. The first is this. That Aristotle has, quite brilliantly, located two contrasting movements-pity and fear-which define how an audience reacts to tragedy. I think the following is what happens, and bear in mind I am talking about the moment of crisis in a tragedy-you know, crazed Agave coming in with the head of her son, for example, and then being enlightened as to what she has done.

When we see that we feel pity, because tragedy invites us to contemplate the suffering of another human being, and therefore our humanity flows out to that person whether we like it or not. We can't help it. If you are a normal human being and you see someone suffering-deserved or otherwise, Iago perhaps excepted-you can feel pity. Now "fear." The fear that Aristotle talks about, remember, is phobos, a sort of screaming terror, and our word "fear" doesn't quite convey that. Personally, I link the idea of fear with self-reflecting phrases such as "There but for the grace of God go I," or with the thought "That could be me." In other words putting yourself in the position of the one suffering. One tragic mistake is all it takes.

If, now, you put those two ideas together-the compassion that reaches out and the fear that touches within-you get a 
sense of the all-embracing dimensions of tragedy. It is as if the play is coming back at you, forcing you to ask questions of yourself. In drama you can experience a kind of pulling apart, or a ventilation, if that is not too comic a word to use. So pity and fear is quite a nice succinct way of talking about an audience's reaction to tragedy. How you direct a play to achieve that is another question. As I have said, you are certainly not thinking of theory when you are directing, but it may help explain the results.

Now, when Aristotle goes on to say, "effecting the proper purgation, the catharsis, of those emotions"-I'm sure he was simply answering Plato who had said, "Get rid of the poets, they're dangerous because they stir up the emotions." Aristotle was saying, "No, the drama calms people and brings understanding."

I think Aristotle was right about the ultimate effect, though I do have difficulties with the word "purgation." When you've gone "through the wringer," that is to say, when you've experienced the full force of a tragedy, you can come out of the theatre actually feeling refreshed and thoughtful; certainly not grief-stricken. The reason why I think you feel good isn't because you've had those feelings purged from you, it's because you've been shown the truth about the human condition and the courage of those who face it. There's nothing quite so refreshing, even if it's not a pleasant truth, as knowing that what you have seen and heard is finally accurate as regards our human condition. I think great works of art always tell the truth; but the drama is special because it is always concerned with the human, with you and me, whether in tragedy or comedy. It cannot fail to do this-unless the production and the acting are so wretched that the audience reach for something to throw. It's as simple as that.

This perception of truth, what is it? It's when what is being presented to you on stage is palpably accurate to the human 
condition as you know it. It reaches beyond any pretences, beyond any sentimentality: it's real; it's there; it is what is. I suppose another way of saying this is that the emotions of the audience have been exercised, not exorcised and certainly not purged. The emotion that has been felt-call it pity and fear-is real, but because it is in a theatre, it takes place in that wonderful world of imagination, of "suspended disbelief." Romeo and Juliet will stand up and take their bow, Agave will come forward and accept your applause. At the same time, what you saw was real on the level of imagination, but not naturalistic: and it was made more real precisely because it was mediated through a work of art. That may have something to do with the quotation from your man Peter Brook, for art does formalise experience.

I also believe that the sense of dignity that a stage character achieves through suffering somehow transfers to the audience. It is good to know that the human spirit can be so strong. The transference is manifest in stillness, and an awareness that the time in the theatre has been well spent. I have seen audiences cry-not in grief, I think, but in gratitude that something true about life has been stated and shared. Common humanity we call it.

David Groves How does your admiration for the plays of Brecht fit with your respect for the Aristotelian text? Isn't Brecht irreconcilable with Aristotelian theory?

Phillip Mann Great. Here we go. Well, Brecht took on Aristotle because he thought that Aristotle was the darling of the bourgeois intelligentsia-I mean Brecht always went for the jugular and that is one of the reasons I like him-and because he thought that Aristotle's theory-i.e., his reply to Plato-justified passivity in a time of danger. Brecht knew the difference between to feel and to do: he knew that it is possible to sob in the theatre about the starving and then go out and enjoy a rare-cooked beef steak and vintage red wine without making any connection between life and the theatre. 
He wanted to challenge that, and how better than challenging the most revered apologist of Western Drama.

But you're really comparing two theories of the drama, and you did say my "admiration for the plays of Brecht." And that is correct. When it comes down to it I deal with the actuality of the texts. Much as I like speculation I do not think of theory when I am directing. Why I don't have a conflict in my heart between liking Brecht and liking shall we say Aeschylus, is quite simply because beyond the reach of theory, both dramatists are telling the truth: about the real world.

But let's just talk for a minute about the apparent conflict between Brecht and Aristotle in terms of emotion. All Brecht asks really is for the audience to consider why something, an event on stage in one of his plays say, has happened. He did not want there to be a metaphysical world which could be used to justify suffering. "Don't blame the Gods," he might say. "They might control the afterlife, but we control the-here-and-now, and we have some real bastards to deal with." Now for the Greeks, the metaphysical world was there, palpably in its temples and its mythology, but Brecht didn't want that because he really wanted people to say: "Listen, there may be a god, there may not be a god, I'm not too sure about that, but what I do know is that there are taxes. Now we control taxes, right? Wrong, the rulers control the taxes! And we can change the social conditions, right? Right! If we organise, work together and seize back our power." You see, he wanted a drama which forced the audience to ask questions or to see alternatives. "It is wrong," he says quite simply, "that there should be anyone dying of starvation. We must do something about it! If a child is scrabbling in a rubbish can for food, we must do something about it." That wonderful poem which he wrote just before he died, you know: "And I always thought: the very simplest words / Must be enough. When I say what 
things are like / Everyone's heart must be torn to shreds. / That you'll go down if you don't stand up for yourself / Surely you see that."-when he wrote that poem he was really talking about the fact that his drama was to teach and warn. Now, if you read the Short Organum he acknowledges several things. First of all that theatre, if it's going to work at all, has got to be pleasurable. As he said, "A theatre that can't be laughed in, is a theatre to be laughed at." Of course people are emotionally moved in the theatre, you can't not be, you'd be inhuman not to be. The question is, to what use that emotion is put. Does it appease one's conscience or prick one's conscience? Is it used to create a better understanding of the world and of society, hence promoting change? Or does it not? If not, Brecht would contend, then it's going to be a bad play; and if it's political, it's just going to be propaganda. But if it is a good play then the honest emotion can be given shock value. The shock wakes up the brain. And the brain starts to ask questions.

That is the secret of Mother Courage. When, at the very end of the play, she bends over, grabs the shafts of the cart, and starts to heave it across the stage with great effort and so forth, yes, your heart moves out in pity. But if you do then ask the question, "How has this come about? Why has this happened? Where are her sons?"- -then Brecht's requirements begin to be satisfied. Unfortunately, in that play the pity tends to overwhelm questioning, and Mother Courage can be seen as heroic and brave rather than a parasite who lives on the war who dickered away her son's life. Such paradoxes are not uncommon in Brecht, nor do they invalidate his ideas.

Brecht never wanted people to run out of his theatre and create a revolution. Not like that [clicks fingers]. He was canny. He knew that a fascist bourgeois state would use such an occasion to justify increased repression. No, education was the only thing which would create a true revolution, and 
that's a long-term project. First you get people thinking: then they start to ask questions. Then they might see folly and venal behaviour for what it is. The process is quite Socratic really.

This idea of learning is linked to something I mentioned earlier, about the slow "coming down" of Greek drama after the crisis, a shift which allows you to become more distant and therefore enabling contemplation. For me that begins to satisfy a lot of Brecht's requirements, never forgetting that his drama is complex, emotional, intellectual and ironic. But the man who sits at a table quietly after a performance, sipping his schnapps and thinking: that man is now bothered, and he might create a revolution because he will talk to his mates and they might start a movement and organise.

Now consider the end of the Bacchae. The punishment meted out to Pentheus, the son, and to Agave, the mother, is disproportionate to the crime committed, and invites the audience to really question whether the gods have any authority, any moral authority at all. How is that different to Brecht? The play can be read as a profoundly anti-religious text. I am reminded of Gloucester's words in King Lear, "As flies to wanton boys are we to the gods, / They kill us for their sport."

David Groves Do you, if pushed, accept a hierarchy of genres, do you think that when all is said and done tragedy is more serious, or important, or higher or... "better" than comedy, because it deals with some ultimate questions?

Phillip Mann Well, tragedy is intentionally more serious than comedy or we really are in trouble. No, overall, I think it's very misleading to think in that hierarchical way. I try not to think that way. Probably the side of me which is awake at four o'clock in the morning wondering "Whither now?" appreciates the tragic mode the most. But at other times I need comedy, simply because it is a different way of 
understanding the world. Comedy laughs at fate and delights in absurdity.

The mode of the present age is tragicomedy - a genre which, as its name suggests, enjoys a bit of both worlds. Personally I have a great delight in farce. I think this is because it depends on the sheer craft of the actor. For me that is something joyful. No matter.

What I am saying is that the two genres, tragedy and comedy, satisfy different sides of what we are as human beings. Or perhaps - if tragedy shows us the way the world is, then comedy is our response, to laugh at its absurdity. When we begin to then take these two apart, we find they have many similarities. It is in their attitude to experience that they differ.

Aristotle may have been a cultural snob in some ways, but by the time he was writing, the great period of Athenian drama, with new plays presented at the festival every year and by poets as sublime as Aeschylus and Euripides ... well that great creative period had ended. So he is looking back to a time when the drama was immediate and played a significant role in public life. I sometimes think that the Greeks were so competitive in their natures, that they always wanted to rank things: one first, one second, one third and so forth. I think we live at a time when we are a bit more questioning of competition as a way of deciding what is best. And I think that if we contemplate the rounded nature of the human being, we'll find that there's room for contradiction and paradox and for valleys to be exalted and hills laid low.

David Groves Just one last question about Aristotle. What do you think of Aristotle's contention that, of the six parts making up the tragedy - spectacle, character, plot, language, melody and thought - the most important is the organisation, the plot?

Phillip Mann Ah this is something different to ranking. Aristotle is trying to work out what makes plays work, what is the 
sine qua non? He talks about plot, and to the modern mind, more accustomed to psychological explanations of drama, that can seem quite sterile, almost mechanical. But I think he is right, especially if we think of plot as being the action of the drama. I am not just playing with words. Action isn't just what's done, but it also contains why something is done and how events are linked. It is the outward and visible sign of the writer's inner intention. The plot is the sequence of events which allows the writer to explore and expand the significance of his story. It allows the writer to access the total background of concern and thinking which will ultimately inform every aspect of the work.

Character explains why Hamlet (say) neglects to kill Claudius when he could. But the basic fact from the plot's point of view is that Hamlet does not kill him. The explanation comes second.

Or Macbeth... The plot says, "Macbeth has doubts about the plot to kill the king." This becomes the marvellous and characterful soliloquy "If it were done when "tis done" etc. And later, it allows the extraordinary character moment when Lady Macbeth says, "When you durst do it, then you were a man..." and the whole play moves on towards murder.

Plot also touches a commonality which we all share-a love of stories. It is because of this commonality that we can have myths and fairy stories, or a special kind of history that satisfies a need in us for heroes such as Robin Hood, even though the story may be historically unsound. And we can have tragedies, these great stories which somehow enshrine some deep truth about what it means to be a human being. Thus plot can be likened to a foundation stone.

So, Aristotle, in ranking the elements of drama in that way, has stated something quite profound about plot: that it is the starting point, the first concrete expression of inspiration, the tangible form which allows the deeper action to take place. It 
is not the first among equal contenders: it is the necessary first.

I was always interested that Aristotle puts Spectacle way down in his list. When I lived in America I was a lighting designer and I designed many sets-spectacle was important to me. I think Aristotle was aware that Spectacle, if given too much prominence, can destroy the plot and hence pervert or at least undermine the meaning of a work of art. I know there are those who would say that the lights, the set, the effects etc. are the meaning. Well, if one pursues this one can end up with what Ionesco called a "sterile polemic." Suffice to say that theatre can exist in a room without decoration and with no more technology than the sun through a window or a candle on a ledge, and no more props than a brick and a sheet of newspaper-but it can't exist without an actor, an audience and a story. And that is the plot.

I would like to digress for a moment and talk about the plots of Greek dramas if I may. In the early days of the drama, when we read the plays of Aeschylus, there is an unpredictability to them which I liken to the avant-garde. I mean, Aeschylus is not so much following rules, but making them. He is discovering drama as he goes. In a play like The Persians, it seems to me that the plot is just emerging from the lyric and becoming dramatic rather than descriptive. Dialogue is also being experimented with. The play deals with the Persian War, as bloody and cruel an event as any, and all Aeschylus needs are a few images to summon up the experience. It would be vividly alive in the memories of all his audience.

As the drama matured, plots became more sophisticated, more layered, and more distanced, but they never lost that immediacy of reference. By the time we come to Euripides' Trojan Women, the action is placed in Troy at the time of Homer, but the reality Euripides is talking about took place 
on the island of-was it Melos?_-just a few months before the play was produced, when the Athenian soldiers butchered all the male children and all the men, and took the women into slavery. No wonder Euripides was feared, but the power of drama to tell the truth was vindicated.

After the defeat of Athens in the Peloponnesian war, the tragic drama begins to lose its immediacy, though the comedy - and here I am thinking mainly of The Frogsretains a bitter nostalgia. But the device of using the past to comment on the present has been born. Though the link is not continuous, the pattern evident in Greek drama remains the same for us in the much later European drama. An irresistible move towards complexity. Using the past to serve the present. Using momentous events to understand causes. Brecht does this in Galileo and in the Caucasian Chalk Circle to name but two plays. Shakespeare too in that most politically savvy of plays, Julius Caesar.

Sub-plots. In good plays, sub-plots are not digressions but ironic commentary on the main plot, and hence tightly bound to it. And so we return to Aristotle who would not have changed his point of view if he had had the good fortune to see Shakespeare's plays performed, though he might have introduced a new sub-category to follow Plot, replacing Character with something called Psychology. And I doubt he would have worried about purgation.

David Groves Phil, can I ask you another question? Shakespeare respected the genres but sometimes scrambled the levels which theoretically he kept apart-there's always prose and poetry as well. Modern critics and modern directors have sometimes interpreted King Lear for instance as a sort of savage farce. Is it legitimate? Is it possible or productive to play against the grain, against the ostensible intention of the text? - to play a tragedy as a comical farce, or vice-versa? How fixed are these categories when it comes down to the nitty-gritty, especially of a play which is so extraordinary in 
its extremes? Where do the categories break down? Shakespeare seems to be pushing them himself, but twentieth-century directors take that further.

Phillip Mann Yes, we have a very mixed theatre at present. But we must never forget that Shakespeare and his contemporaries such as Ben Jonson were all developing and discovering the drama as they went along. Just as in a way we are. Genre is finally a blunt tool. The more you examine genre in specific works the more you find how variable it is while yet retaining some coherence. I think in a question such as you have proposed, one can distinguish between new, or different or radical interpretations of a work, and playing against the text. To me, expanding interpretation is the very heart of directing, for it is part of an evolutionary process. Each age discovers its own Hamlets. Deliberately playing against the text seems to me to be a bit of an intellectual game... or a bit like Dada. But whereas Dada was necessary in the early part of the twentieth century for a variety of reasons, to repeat it in the modern theatre would simply reveal one's own lack of originality. I do not mean to seem hard, but to play against the text seems to me perverse. I do not know what is being aimed for.

At the same time, I am happy to see plays dismantled in order to serve another function. Stoppard does this brilliantly as in his own way does Brecht. Jean Betts in Ophelia Thinks Harder gives a wonderful radical feminist twist to Hamlet. At Victoria University of Wellington, a production such as The Tragic Consequences of the Assassination of Julius Caesar as Performed and Devised by Cinna the Poet has a lot of fun at the expense of Shakespeare's Julius Caesar, but it is finally deeply serious regarding the deliberate manipulation of language and rhetoric and the consequences are indeed tragic. Finally, when I directed Julius Caesar at Circa I set it in the modern age of machine guns and cell phones. Mark Antony became Antonia played by a woman. 
Casca too was played by a woman. The funeral oration took place in a TV studio, etc., etc. I am still astonished at the wonderful things that emerged as a result of this interpretation, without being in any way untrue to the spirit of the original play.

However, when you first mentioned this question, lines from King Lear came flooding through my mind. I was thinking to myself: how could I make lines such as

When we are born we cry that we are come

To this great stage of fools. This a good block:

It were a delicate stratagem to shoe

A troop of horse with felt. I'll put it in proof

And when I have stolen upon these son-in-laws,

Then kill, kill, kill, kill, kill, kill!

The intensity is dangerously mad. One could perhaps play around with it but I think you'd always end up in a Becketty sort of world.

I think part of my problem here - and with some modern productions - is that I believe that it is playwrights who are the great innovators in theatre, not directors. Directors interpret and find new meanings. But it is only playwrights who have the deep skills necessary to disassemble and create something new.

David Groves You said Beckett. The twentieth century has tended to scramble all those categories that were introduced with the Renaissance, and some critics have said that tragicomedy is the characteristic form of the twentieth century. How does one, if we wanted to, fix a generic label on Six Characters in Search of an Author or Waiting for Godot...?

Phillip Mann Mm, I don't think one can. Well, not easily. Six Characters in Search of an Author is a fine play and somewhat revolutionary in its time, but it did not change the world. Waiting for Godot did. If you don't mind I'd prefer to 
talk about Godot. Quite simply, Waiting for Godot is one of the most original and poignant plays of the twentieth century and perhaps of all time. It is almost a genre on its own. It exemplifies what I was saying about playwrights being the great originators whose plays challenge us directors to find ways of directing them - that is if we respect texts and don't just want to muck them about. At the same time, I think it is correct to say that the twentieth century is the age of tragicomedy-however, I think it is a somewhat meaningless category: a pot-pourri, an amalgam, lacking a clear definition but accommodating a great range of work. Six Characters in Search of an Author would find a home there, but so would Genet's Le Balcon. I would not, however, include Waiting for Godot. It is itself, unique, and far transcends the somewhat old fashioned notion of Theatre of the Absurd.

David Groves What twentieth-century plays would you point to as having identifiable in them for you that tragic theme or intent or power?

Phillip Mann The Devils by John Whiting is one that springs to mind immediately. It is based on a true character, the brilliant and sensual Urbain Grandier who lived in the early part of the seventeenth century in France. In the play he is destroyed by petty jealousy, ignorant superstition and fear in high places lest his eloquence and popularity undermine the state. There is tragic waste a-plenty, and his final death at the stake is the result of his stubborn faith and to that extent it is heroic. It fulfils all the criteria for tragedy I mentioned earlier. The film made by Ken Russell on the same story does not.

Woyzeck by the German playwright Georg Büchner is also a contender. I know it was written in the nineteenth century but it was ahead of its time in many ways and was not produced until the twentieth century. It has also been described as the first working-class tragedy, because the 
hero is not heroic, but an ordinary man who suffers until his grief drives him to death.

One also thinks of the plays of Arthur Miller and Tennessee Williams. The tragic is still alive and powerfully so. It is just that we no longer use the old genre names because they carry such a freight of expectation and could actually mislead us regarding the contemporary works. God forgive that we should ever fall into the trap of ascribing the three unities etc. to our drama - though interestingly, Waiting for Godot fulfils them all and that, paradoxically, may explain some of its power. Interesting, eh?

Moreover, it is a fact that sometimes, in the modern theatre, we use the comic to make a tragic point. I am thinking of the play Bent by Martin Sherman which I directed some years ago. It deals with the persecution of homosexuals in Dachau in the 1930s. Fierce stuff! It is a tragedy, according to all the terms which we've talked about; but if you made it too harrowingly real - too much phobos, let us say - and thereby frightening to the audience, you would lose the tragedy. Sometimes the effectiveness of the drama occurs in those wonderful transitions which occur when something moves from being horrific to being just serio-comic, and then goes back to being tragic again. The audience is being played by the play, in a very subtle, but very telling way. Shakespeare does this too.

In Vincent O'Sullivan's play Shuriken, the killing of the Japanese soldiers on stage, wrongly handled, could be comparatively comic, but it mustn't be. It is, in a classical sense, the crisis after which the play has a gentle elegiac ending which leaves everything intact, but different. 
However, I don't think I would call it a tragedy. It is a very complex play to define. ${ }^{1}$

In the modern theatre we have so much freedom, and while sometimes that might lead to slackness or a lack of definition, it is also true that we can be partly comic when we are at our most serious: and straight faced when we wish to induce a smile. I think the epitome of this is Chekhov.

David Groves I want to talk soon about particular productions. But I just wonder whether working even with, or especially with, professional actors-I say "especially" because they have their defence mechanisms and their habits which help them survive-do you feel there is often a resistance to seriousness? And then audiences like to laugh. The first reaction of some audiences to someone coming onstage and saying "Kill kill kill kill" might be to laugh. It has to be done extraordinarily well, otherwise it becomes not comic in any technical sense, but it just becomes bad so it's laughable. People are more comfortable laughing, a laugh can become a defence.

Phillip Mann Absolutely. An avoidance.

David Groves So you're getting into tricky territory when you want an audience to be "played by the play." Do you find tragic seriousness difficult for actors and audiences to cope with?

Phillip Mann No. The big secret is to establish your conventions very firmly at the beginning so that the audience know where they are and so do the actors. I don't have much time for trickery with the audience, again my love of Brecht comes out in me. I like the audience to feel comfortable: they've come to see a play and we're going to give them the very best we can, and we really want to display our art to

1 Editors' note: on Phillip Mann's production of Vincent O'Sullivan's play Shuriken, see Phillip Mann, "Tragic Power in Vincent O'Sullivan's Shuriken," Australasian Drama Studies 18 (April 1991): 91-94, 147-58. 
them, and for them to really enjoy it, including the very serious bits. And yes, we will surprise them, and that is nothing to be afraid of.

The very style of the production may indicate that there are serious events but they're going to be treated in a farcical manner. This can be very clear from the beginning. I am thinking of a play called The Suicide by Nicolai Erdman. In this play, which was banned for many years in Russia, there is a young man called Semyon who wants to kill himself. This becomes known and then people start to approach him saying, "Would you do it for my cause?" He ends up almost getting trapped into having to kill himself. The tragic and the comic lie side by side, laced with considerable satire.

If you establish the conventions very firmly at the beginning, then you are free to develop the play as you will. Actually, this happens almost automatically. Thought and style work together.

If your play's going to be serious, King Lear for example, then it declares itself very early on. Thus, the lines "Kill kill kill kill" etc., coming very close to the end, are supported by a massive structure which has already been established, in a totally justified and warranted manner. I think the audience would kill anyone who laughed at that.

David Groves Have you directed King Lear?

Phillip Mann No, sadly. I've always thought I'd love to have a go at it, but it frightens me. I'd want the very best of actors. I've only ever directed bits of it really, but that was enough to feel its heat. You asked about actors taking things seriously. I don't think that has ever been a problem for me, except perhaps once in a Brecht play.

But the way actors work their way into the great roles is very important. It is a mistake to go for the big tragic effect too quickly. You should let the drama work its own magic. Bent is a case in point. I quickly realised that if we went at this play too directly, we'd get stuck. So we treated it very 
lightly, and there was a lot of humour in those early rehearsals. But then, as the actors became more comfortable in their roles, I can remember watching and thinking, "The play is starting to take over the actors. It's starting to work." There were still comic things happening, but they were a kind of safety valve and the scenes were never broken. And strangely, it is when the play is starting to work that you can put little light comic things back into it. I'll give you an example of what I mean. The first time in Bent we meet Uncle Freddie who is a very gentle, very vulnerable, totally unassuming older gay man, we decided that when the lights came up, he would be just standing on stage holding a collapsible chair in one hand, a glass in the other and with his newspaper in his mouth. He was looking for a place in a park where he could sit down. What a lovely pathetic and yet comic image this was of harmless frailty. It is things like that, those little details which are comic, but they allow the tragedy to work. The little glimpse of comedy gives distance. It gives us breathing space... while in the wings, we know the menace is gathering strength.

$$
* * *
$$

\section{Particular productions}

David Groves Have you ever felt yourself, in dealing with one of these big classical or Shakespeare tragedies, help! I'm drowning? When you've felt that you've lost your bearings a bit?

Phillip Mann No. The only time I feel anything like that is when I know I am going to be directing a major play but one which I do not know well. I suppose I'd have to include King Lear in that. I mean I know the play, but not in that intimate way one knows a play when one has directed it. 
The lonely feeling comes before I start serious work on the text. And the only way to get rid of it is to have a passionate affair with the play. Again, I choose my words carefully, because it is like a love affair, just beginning. I usually start to read the play very slowly, stopping often to make sure I know what I am reading, and not wanting to make decisions or let the play become too theatrical too soon. I am not looking for drama at this time, but merely to understand what is happening in the text. But inevitably, connections come alive, possibilities present themselves. I talk to people who know something about the play, finding out what they think. Also, if it is a translation I find different versions and compare them. With the Bacchae I read three translations and ended up creating my own text from those I had read, and I rewrote some bits for myself, especially for the choral sections.

Then, almost without my knowing it, a moment of the play comes alive. And this, because it is a single integrated work, starts to make sense of other parts of the play. Soon I know why scenes are where they are-I am reading the playwright as it were, the plot-and I have a sense of the emotional rhythm too. Those two words, emotion and rhythm, are very important. It is the structure-very close to plot-which first comes alive for me.

And then I start to get excited - the play is revealing itself, and I even begin thinking about casting. I have never directed a play that I have not come to love. It sort of "goes with the territory" as they say.

Let me add one last thing. It is important not to go too far in one's planning. You must leave a lot of room for the actor, for the play will change depending on who is cast. I think this is where a number of directors go wrong. They want to see the finished play in their heads: and all I can say to that is that from my experience they are denying themselves the most exciting journey of all, for actors are the life-blood of 
the drama. Suffice to know that if one's ideas are good and sturdy, they will survive and strengthen. However, I have one little dictum. It came to me one day. It is simply this: "Good ideas solve problems. Bad ideas create them." Sometimes plays just unfold - that is because the ideas are good. Occasionally, nothing seems to work and you have to go back and find out where it went wrong. The cause is inevitably a bad idea which led to unnecessary complications.

David Groves Let's talk about Othello. I didn't go to see the Othello brought by the National Theatre to the International Festival, for two reasons. First, because I've come not to trust the English very much with Shakespeare!-I've often been bored, I've walked out of the National Theatre more than once. And then, you've just got to feel up to it! Can I take on Othello tonight? It's such a remorseless play!

Phillip Mann It is indeed... Well I hope in the production I did you were not bored, because I think there are certain things in the play which I discovered, and which ultimately gave the production its impetus and about which I was very pleased. After I had read the play and the notes and talked to colleagues etc., my starting point was Iago. It was the way he speaks to the audience in his opening soliloquy that intrigued me: taking them into his confidence, winning them just as he wins Othello. And I could imagine that as he seduces Othello and pours his poison in his ears, he might also look into the audience-who are now in a way his accomplices, by association if not by intention - and wink as if to say, "See how it is done. So easy." This, of course, puts the audience in a morally complex position. They cannot condone what he does, but who is going to stop him? Everyone in the play thinks he is honest. Only the audience know what he is up to: and are they going to do anything? Can they? Can they? Actually, one night someone in the audience did call out to Othello, "Don't trust him." This 
dilemma-or perhaps it is a manipulation of the actor/audience relationship - was my starting point for the entire production.

Before casting, you must begin to understand the architecture of the play. So, while I was thinking about Iago, I was struck by the fact that most of the key men in the play are weak in some way. Iago is what he is, the epitome of perfidy against which our good nature is no defence. The only decent man who matches him is Lodovico who is sensible and compassionate, just and ruthless when dispensing justice. The other three men, Roderigo, Cassio and Othello, have enormous flaws. Roderigo is besotted with love for Desdemona and this has unbalanced his judgement. We can feel some pity for him, but he is a fool finally. Cassio is a lady's man, a pretty boy who uses his charm to get women to serve him. He is vain, and a manipulator in his own way, who wants Desdemona to intercede for him rather than face Othello himself. And Othello? While he is decent and honourable and a great man's man who is good at fighting, he is fundamentally ignorant of how the world works. He is innocent and unworldly, and there is something virginal about him. He certainly does not have much knowledge of women or of love for that matter. Now, contrast these three with the three women in the play. All the women are capable of deep love. Bianca is a prostitute, who accepts her sensual nature and falls in love easily and tempestuously. Like Roderigo and, indeed, like Desdemona; because she is in love, she is vulnerable. Then there is Emilia, Iago's wife, a highly intelligent woman of the world: sensual, one suspects, and realistic possessing her own home-spun morality. She loves Iago and wants to please him and perhaps that blinds her to his perfidy, until the end. Finally we have Desdemona who, when she gives herself in love, gives everything! She cannot conceive of deceit: she cannot conceive of being faithless. To her if you say you 
will do something, that is your bond. Like all Shakespeare's great heroines she is intelligent and playful and totally at home in her body and her passions, and the body will follow where her heart leads. I mention these things because it is important that we never think of Desdemona as being aloof or a bit frigid. An awareness of sexual passion-albeit held in check - is important in understanding both Othello and Desdemona.

So! Consider these three women. There is a kind of trinity here: Bianca the earthy, Emilia the worldly and Desdemona the spiritual. All of them frankly at home with their sensual life. Now, compare them with the men! There is hardly any comparison, except that the women have the love and the men have the power. I claim nothing for this on the level of literary scholarship, but it is a working hypothesis for the theatre because it defines the emotional structure of the play.

David Groves The formality of it!

Phillip Mann There is a formality to it indeed. You are right, but it is somewhat hidden. However, with this structure in mind, the next thing was to cast the play and I now knew what I was looking for. I realised that it was the ending I had to get right. Bianca has no part in that. Desdemona is dead, and thus Emilia is the key figure.

Let's look at the ending. (Phillip Mann gets his text of Othello.) Othello has done the deed. Desdemona is more or less dead. He has killed a woman who loved him and whom he loved, and who was probably the purest thing he could conceive of. The fact, the tragic fact, is that there is no redemption, the deed is done, and as with Macbeth, there's nothing he can do. He can say he's sorry until the cows come home, but it's not going to bring her back to life.

Methinks it should be now a huge eclipse Of sun and moon, and that th'affrighted globe Should yawn at alteration. 
We are coming now to the scene that interested me. Emilia, all excited with her news about Roderigo and Cassio, has come knocking at the door. For fun, and because I felt confident of my own interpretation, I went back and looked at the Laurence Olivier film. I was astonished to find that much of Emilia's part had been cut from this part of the play. True! I was gobsmacked. They had cut material that I thought was crucial to the emotional meaning of the play.

And now I want to explain why I think that is so.

Emilia comes in and gasps out her news that Cassio has killed Roderigo but is not dead himself. The plot worked out by Iago and Othello is starting to break down. Desdemona, still not quite dead, says, "A guiltless death I die" and when Emilia demands to know who had done this deed, Desdemona tries to take the blame on herself, presumably to save Othello.

Othello's first reaction is to lie and pretend he does not know. This is important because it shows how far he has fallen from his own honest nature. It also indicates something else: the extent to which evil and corruption and lying have contaminated everything. The very atmosphere is tainted.

Othello rallies and confesses his guilt in an angry blustering speech, "She's like a liar gone to burning hell: / 'Twas I that killed her." But it is too late, the audience has heard him lie, and is going to turn from him. And observe Emilia now. She is not frightened by his bluster-because he can frighten people can Othello if you play it properly. Her immediate reaction is to face him and confront him in defence of her mistress: "O, the more angel she, / And you the blacker devil!" For the first time, for a long time, someone is fighting back against the lies and deceit. 
From this moment on Emilia grows in stature as she grows in rage. With incredulity she absorbs the news that Iago has had a hand in things:

Emilia My husband say that she was false?

Othello

$\mathrm{He}$, woman;

I say thy husband. Dost understand the word?

My friend, thy husband, honest, honest Iago.

Emilia If he say so, may his pernicious soul

Rot half a grain a day! He lies to th'heart.

She was too fond of her most filthy bargain.

And now, having grasped the truth-in what, incidentally, Aristotle would define as an anagnorisis-Emila goes on the attack. She is magnificent. She rips into Othello, excoriates him. The words tumble out, unpremeditated, direct and mingled with her grief. No one, in his experience, has ever spoken to Othello like this. He threatens her, and she stands her ground in front of him, daring him to kill the truth.

Othello Ha! (He is threatening her with his sword or dagger)

Emilia Do thy worst.

This deed of thine is no more worthy heaven

Than thou wast worthy her.

Othello Peace, you were best.

Emilia Thou hast not half that power to do me harm

As I have to be hurt. O gull! O dolt!

As ignorant as dirt...

and so it grows until she is shouting for all the world to hear, "Murder, murder!" at which point Montano and Gratiano come rushing in, and with them is Iago.

Emilia, now in full authority, confronts Iago and demands the truth.

And little by little it is revealed: the lies, the half-lies, the trickery with the handkerchief, everything! And Othello-in what I think would be called by Aristotle an anagnorisis 
followed by a peripeteia or reversal-hears the truth and learns what he has done.

On a deeper level, on a philosophical level let us say, truth is cleansing the play. The audience can feel it. Though she dies at the hand of Iago, Emilia has stood forth like the decent, thoughtful, loving and loyal woman she is. One almost wants to weep at the pity of it. Emilia asserts the morality which has been negated throughout by people like Iago, and the world is the better for it.

Although I said earlier that Shakespeare's tragedies tend to end with a punch, and while Othello is no exception, the play also ends with a sustained cleansing. In some ways this is akin to the contemplation one finds at the end of Greek tragedies, though there is nothing really Greek about it.

Othello has no room for any manoeuvring after all has been revealed. He is damned, and nothing he can say or do will possibly eradicate the crime. Any amount of grief he feels, there is still a dead woman lying in his bed.

David Groves So what do you make of his final speech?

Phillip Mann It's full of obfuscation. I think it's one of the most painful speeches in the whole play, and try as I would, try as I would, I could not find anything of redeeming dignity in it. I actually feel that when he goes on his language is vain and irreverent, though I must say I do not claim this was Shakespeare's intention.

Behold, I have a weapon:

A better never did itself sustain

Upon a soldier's thigh. I have seen the day

That with this little arm and this good sword

I have made my way through more impediments

Than twenty times your stop.

This vain language!

Because of what Emilia has said, you don't see a great hero, you see a dolt, you see a fool, you see a vain person, 
ignorant as dirt, but who has always got his way because he could speak well and could fight well and was fair minded. But yes there is a sense of waste. He had at least won the hand of Desdemona and she was no fool. However, the audience see the iconography of the stage - a dead woman and her murderer still living and talking.

Everyone, the audience and the characters on stage, are just looking at him. In their minds they are saying, "Go on, talk all your fill, you're never going to get away with this." So when he finally says, "Be not afraid, though you do see me weaponed...," it is quite laughable really, because he has no mana now.

I have no doubt he's feeling remorse, but we the audience don't sympathise with his feeling. The situation is totally different with Lear when he comes in with dead Cordelia in his arms, or even Macbeth when he says, "Lay on Macduff, / and damned be him that first cries "Hold, enough." There you are drawn towards the suffering of Lear because it was so unmerited and to the raw courage of Macbeth in fighting on to the end though all is lost. But here, with Othello, there is nothing he can say or do that can possibly redeem him.

To bring this out clearly, I chose one moment to have him fumble with the dagger. Everyone can see what he is doing, and everyone knows what he is planning to do. I had Cassio step forward as though to relieve him of the dagger, but Lodovico stops him with a shake of his head. Lodovico is saying: "Let him kill himself. That's the last charity we can offer. Let him kill himself, because if he goes back to Venice, he's going to die anyway. Save the state the trouble."

So Othello kills himself, because that is the only avenue left open to him. And now we are left with Iago. Who can explain Iago? Nobody can. And we are fortunate that such creatures are comparatively rare. But Lodovico, whom I see 
as the only truly honest man in the play, has his measure. Hear his final words on Iago.

Lodovico

To you, lord governor,

Remains the censure of this hellish villain:

The time, the place, the torture, $\mathrm{O}$, enforce it!

Those last three words are like a hidden command. And we know then, that within minutes of the play's end, Iago will be screaming under torture unto death. It is a fierce ending. But like burning down a house where a murder has taken place, it is the only way to cleanse everything. There is no rule of law that can deal with Iago's perfidy. (Pause)

David Groves Let me tell you one of the things that really annoyed me during the Festival of the Arts - did you hear, they were talking about the play on the radio-I think it was the director, it may also have been the actor who played Othello, or was it Iago? - and they only talked about the male characters; and they said that working on the play they suddenly realised it was Iago's tragedy too.

Phillip Mann B*llsh*t.

David Groves And I thought: Hang on a mo'! What about Desdemona?! What about Emilia? What about all of them? Even Cassio has had to face himself! But what about the women? I remember being really offended at that point.

Phillip Mann That's my glass of wine you're sipping.

David Groves Oh sorry!

Phillip Mann No worries. But you're absolutely right. I heard that, and I thought Bugger! - they're doing the same thing. They've made it into a male play... Are they going to ask us to feel some sort of sympathy for Iago? I listened to the actor playing Iago saying: "Oh well, I begin to feel there's a certain tragedy in Iago. We're going to have sympathy for Iago." You really do muck up the moral lines of the play if you do that, you really do. But if you let the women be the 
cleansing of the play, then everything makes sense, doesn't it?

The secret of playing Iago is to make him completely plausible, and likeable. The kind of man you might think, "Yes, I wouldn't mind having a drink with him." This is what we did. But with just little flickering moments when he reveals himself as almost insane in his anger and hatred and jealousy. These occur when he talks to the audience. He is the only one who has the right of soliloquy. All the other characters are trapped, as it were, within the play. You know it is one of the laws of soliloquy that you cannot lie. You cannot lie because what you say is the mind speaking. In our production, Iago charmed the audience by his manner. He comes across as a bit of a rogue - a dark harlequin let us say-and it is only later when we see the consequences of what he is doing that his true nature becomes apparent. But in the real world, our world, he would fool you, me, everyone, all the time, hundred per cent. Frightening isn't it? David Groves Does tragedy face us with the fact that evil exists?

Phillip Mann That's a tricky one. I don't think we can say there are evil major characters in Greek drama. I mean they may seem evil to our eyes, but I don't think the Greeks saw it that way. Even Medea is meting out justice-albeit in a brutal way. There are different levels of sophia or wisdom. It is lack of sophia, in other words "ignorance", that leads to suffering: hubris, or pride, does too. And there are people with a bit more knowledge who can perhaps navigate their fate somewhat - though poor Antigone gets walled up alive for honouring the gods. The only character I can think of who might come close to Iago is Dionysus in the Bacchae. But that's not really a tenable comparison. Dionysus is a god, answerable only to himself, and I suppose he is also a symbol of the unpredictability of life. Remember the Greek proverb "Call no man happy until dead." 
Evil becomes a potent force once we get the idea of a Devil, and that goodness is something to be striven for. Is Iago evil? Indeed he is, because he does know better and therefore chooses to act the way he does. He's not ignorant; he's knowledgeable. But yes, I think a Christian context is necessary for evil to become a distinct element. I've not really thought about it in that way.

David Groves It's just that there are things that have happened in our century that I don't think any art can make sense of.

Phillip Mann That should not stop one trying. You can if you like say the play Othello teaches a lesson. And that lesson is to be in your guard, and to stand up for the things you believe in among which are love and honesty. But it is a pretty trite lesson given what happens in the play. If Emilia had been frightened by Othello's bluster, the truth would never have come out. But she wasn't, because in her heart she was decent. A lot of people are decent. In fact most, I think.

David Groves It was Cathy Downes who played that part, wasn't it?

Phillip Mann Yes, she was wonderful, wonderful. But I was also blessed in my Desdemona. Dulcie Smart gave a magnificent performance. Finer than anything I could have hoped for: a profound depth of feeling, mature understanding and yet with an ability to project love and trust. But then there was George Henare, one of New Zealand's finest actors, making Othello come alive, and Ray Henwood as Iago... I mean this was a cast to die for... We, that is me and the audience, were very lucky.

David Groves Why did you do Othello rather than one of the others?

Phillip Mann I was asked to direct it. As I said before, it's easier for me when that happens. I actually don't like choosing plays, because plays when I read them exist in a sort of limbo of potentiality. I actually find plays hard to read 
because I start directing them in my head, and that can become very frustrating. But, if someone comes along and says would you mind directing (say) Measure for Measure... then suddenly everything, the world, the universe starts to change, because Measure for Measure suddenly starts to emerge as a work to be tangled with. I must say Othello was not a play I knew at all well, so I came to it with very fresh eyes. But by the time the play went on I knew almost every word by heart and I felt completely in tune with it, completely at home in the universe of the play. I think you could have asked me any question and I would have had an answer in terms of what we did. Whether I would be right or not is something else. Can I just say I felt very proud of what we achieved because it is not an easy play and the actors and support crew gave of their best.

David Groves Your idea of the "universe" of a work.

Phillip Mann Yes, absolutely. For example, I could see the world through Cassio's eyes and understand his dilemma and the way he grows in stature as the play progresses.

David Groves Who was your Cassio?

Phillip Mann Stuart Devenie. I knew where I was with Lodovico too. I was very careful in casting someone like Lloyd Scott as Lodovico, because Lloyd... he's got a child-like innocence and playfulness about him sometimes, but that can be turned to advantage in a play like this. Lodovico is a very moral being and is truly horrified and offended at the way Othello treats Desdemona. His aristocratic disdain at the end is chilling and he is ruthless in his dealing with Iago.

David Groves Let's go to Agamemnon, at Downstage. What did you learn through that experience?

Phillip Mann Well, that was a play I knew quite well, having taught it in class. Tolis [Papazoglou] and I and Robin Payne worked for some months on a new translation and that was very exciting. Then I was away from New Zealand for a time and when I got back, rehearsals were already underway. 
I attended a rehearsal so that I could catch up and it was the music and the dance that bowled me over. A whole new dimension opened up before me. I had never heard these wonderful chants and funeral songs before. Some of the lamentations go back... well, their origins are lost in antiquity. It was like stepping back in time to a pre-Christian world, and into a world seething with pride and hatred and burning revenge leading to murder. Everything seemed bigger than life, as we know it. So good work had been done in my absence.

David Groves Where did the songs come from?

Phillip Mann Tolis, who is Greek, found them. He and I were more or less directing the play together. That was a strange experience, I admit. By and large it worked well. But some things did happen which I didn't agree with. I would have liked to use the ekkyklema - that's a kind of platform that was rolled on stage towards the end of a tragedy to gain a spectacular effect. I felt that we needed to see the corpses of Agamemnon and Cassandra at the end of the play. The image of the dead couple sums things up and becomes a point of reference for the final speeches of Clytemnestra. She says, in our translation, "See this, my husband. I struck him. Darling of the fancy women of Troy! An outstanding act of justice." This is where Aeschylus is brilliant, such a powerful dramatic imagination. Just when you've gone as far as the drama can take you, just when you've been harrowed by it, Wham! he brings the victims on stage, and that's the final abiding image. It's a bit like having the dead Desdemona and Emilia lying there on the bed during Othello's final speech.

I think we needed something like that so the rhetoric would have a clear focus. And you see, if you don't introduce these spectacular moments, you run the risk of falling into the trap of naturalistic conventions, and the Greek plays are not that. That's the one thing you've got to avoid. These plays exist 
in a purely theatrical world, which is unified, consistent and full of action in itself. It is not a mirror of our actual world: it's a world that is elevated, and resolved and clarified.

But I don't want to concentrate on things that did not happen. We had so many good things and the audience certainly appreciated the bold staging. We were also blessed with a terrific cast led by Carmel McGlone as Clytemnestra. David Groves Wasn't she good!

Phillip Mann I thought Carmel was just magnificent. Frightening in her intensity and rage.

David Groves Did you suffer from the relative smallness of that space in Downstage?

Phillip Mann It never bothered me, it never bothered me at all. I was delighted at the way we had built a small Greek theatre in the middle of Downstage. It worked very well, I thought. Very memorable.

$* * *$

\section{Music and opera}

David Groves What is the importance of music to you in theatre and your tragic productions?

Phillip Mann: Fundamental. You can do things with music which are almost cinematic. You can amplify an emotion, create a context within which something happens, and you can give point, sometimes ironic, to the action. When I was talking about Greek Drama, I mentioned the dances and songs we used in Agamemnon; well, they established the tone and the context for the action with precision. I suppose I should add that one can also wreck a production with the wrong music. 
David Groves One of the interesting things in your career is that I've seen happen to you something that happens almost inevitably in Italy: directors gravitate towards opera. Maybe because it's that totality of the theatrical experience, the strength and depth of the emotions taken way beyond the realistic.

Phillip Mann How interesting. I never thought of that. Opera was quite a new world to me. I've loved the modernity that has come into opera over the last few years, especially in French and German productions. I would have liked to do more opera, something massive like Nixon in China, but the opportunities do not come every day. I would have liked to serve an apprenticeship too, rather as I did in the theatre. It must be wonderful to be immersed in music and to work with singers who really want to act and experiment.

When I directed Hansel and Gretel I appreciated the energy that the mezzo soprano Patricia Payne brought to the role of the Wicked Witch. She showed that singers can move and be flamboyant even when reaching for that top note. That production was quite an eye-opening experience for me. In a way I was lucky that my first opera was so complex and difficult. There were some tantrums - and they are just a waste of time-especially when the time frame for getting the show on is so short. But on the whole the vitality of the opera carried us through, and the music is great fun to create movement to. The set Raymond Boyce designed had some wonderful transformations built into it-very theatrical in what is, I suppose, an almost nineteenth-century way. I think we used every hanging bar in the opera house! It was very complex. One nice memory is to do with the orchestra. When we flew the witch for the first time, the orchestra could not see-they were down in the pit of course - so all they could hear were the bravos and then clapping when, after several tries, we finally got the witch to fly right to the back of the stage in a zig zag formation. A member of the 
orchestra said to me how neglected they felt that they couldn't see all the fun. So I arranged a special viewing for the orchestra, and I think that more than anything made them feel part of the show.

Hansel and Gretel was a steep learning curve for me. I approached my next opera, Madama Butterfly, in a far more concentrated way. And I simply loved it, everything about it. I think the dramaturgy is as near to perfection as any work I know. Puccini does not miss a trick. People said it was a traditional production. Well, I wouldn't really know. I followed Puccini closely because I could see the density of the emotion and the speed with which he could change moods. I was grateful too that there were no temperamental problems. I actually ended up doing two productions, the first in Christchurch and the second in Wellington. One thing I did ask of the singers playing Butterfly was that they stay on stage during the long night vigil. It actually lasts only about ten minutes, but Puccini gives us evening, then night, then dawn, and the time seems much longer — which is of course what he intended. So there is Butterfly, sitting up waiting for Pinkerton to come to her, and I wanted the audience to see her endure the whole time. Of course I made the singers, Suzanne Prain and Dame Malvina Major as comfortable as I could... but they had to sit still as a statue while the lights changed round them, isolating them in the darkness before the first rays of dawn bring the garden alive. That is I think one of the tragic moments. It reveals the profundity of her love and the pain of her disappointment. I know that Puccini arranged it so that the singers could have slipped off stage, but that was a kind of concession. Our New Zealand sopranos stayed on stage, and I was deeply grateful to them. The other somewhat innovative thing I did was to make Sharpless, the US Consul, a more decisive presence. I felt his admiration for Cio Cio San and his 
enjoyment of her wit and his growing disapproval for Pinkerton, and I tried to show these things.

When I think about it, music has always been fundamental in the plays I direct. For the Bacchae at Downstage I built my first piano-harp. First you remove the big heavy string board from the piano. Then you remove all the strings which were struck by the white keys. You now have a pentatonic instrument: just the strings for the black keys are left. If you play with this for a while, you find you can create any kind of mood you want by striking or stroking or plucking the strings. It has a lovely ethereal quality-rather sad and other-worldly. A characteristic of the pentatonic scale is that it never resolves... there is always a sense of the music lingering as though there is more to say. That is perfect for transitions. I have used the piano-harp in several productions.

For Bent, the play we were talking about earlier, I decided to use music in a different way - to evoke mood yes, but also for contrast and irony. We found a record of Joseph Schmidt the tenor, singing lyrical German songs. His beautiful voice and this jolly romantic music was used to counterpoint the terrible beatings and suffering that were taking place on stage. The irony is that Schmidt was Jewish and he died in an internment camp in Switzerland in 1942 after trying to escape from the Nazis. If you want a sense of the lyrical beauty of his voice there is a recording of him singing Ständchen (Serenade) by Schubert on U Tube. When I listen to it, I think of Bent and Dachau.

I've talked about Greek dramas and suggested that one of the ways to approach them is to think of them as avant-garde works. Another interesting thing is that they support highly imaginative use of music. When we staged Trojan Women at Drama Studies many years ago, Michelle Scullion the composer-who was then a student—not only composed some evocative music for trumpet and flute which was 
performed live, but she also used the songs of whales. Those sad unpredictable melodies reaching out from the darkness of the sea matched the tragic situation of the women perfectly. Much later when I directed a version of Aeschylus' The Persians - a production which we expanded to include aspects of the First World War and re-titled They Shall Not Grow Old-I remembered Trojan Women. I didn't use whale songs, but I happened to visit a garden-centre during a Wellington southerly. The wind chimes were going crazy. What music! I set up fans behind the curtains all round the theatre and hung wind chimes so the draft would keep them sounding. Thus we had the whirl of the fans, the rustle of the curtains and the strange distant tinkle of the chimes. It was quite beautiful, but eerie too. It helped unify the two worlds of warfare-separated in time by 2,500 years - and at the same time suggested bleakness and cold. Perhaps this is more a sound effect than music, but it was certainly musical. And it could be controlled and stopped at the flick of a switch.

Brecht of course wrote for a musical theatre and had composers as varied as Kurt Weill and Paul Dessau and Hanns Eisler. While no one would dream of changing Weill's music for the Threepenny Opera, feelings differ regarding the other composers. My own inclination is that while the original music is often very appealing, there is a lot to be said for having music specially written for a new production. We did that for The Good Person of Setzuan in which you performed one of the three Gods. The music composed by Rod Jenkins still haunts me.

I wonder if you remember this sad little song which was sung/spoken.

A day will come, so the poor were informed As they sat at their mother's knees

When a child of low birth shall inherit the earth 
And the moon shall be made of green cheese.

When the moon is green cheese

The poor shall inherit the earth.

I could go on.

But, that is a good note for me to end on.

$* * *$ 